\title{
DETERMINANT OF NON PERFORMING LOAN: THE CASE OF ISLAMIC BANK IN INDONESIA
}

\author{
Irman Firmansyah ${ }^{7}$
}

\begin{abstract}
This paper analyzes the non-performing loan and its determinant. Using the monthly data of Islamic banks during 2010-2012, this paper found that size and efficiency of the banks do not affect the non-performing loan. On the other hand, GDP and inflation negatively affect the non-performing loan, while the liquidity of the bank positively affects the non-performing loan. The liquidity of also does not mediate the relationship between the size of the bank, their efficiency, the GDP and the inflation to the non-performing loan.
\end{abstract}

Keywords: non-performing loan, liquidity, bank size, efficiency, sobel test, Islamic bank.

JEL Classification: C12, G21

1 Lecturer at Department of Economic University of Siliwangi Tasikmalaya, and a consultant at Smart Consulting, email: irmanfirmansyah@unsil.ac.id. 


\section{PENDAHULUAN}

Bank merupakan lembaga keuangan yang terpenting yang mempengaruhi perekonomian baik secara mikro maupun secara makro. Fungsinya sebagai perantara keuangan (financial intermediary) antara pihak-pihak yang surplus dengan pihak-pihak yang membutuhkan dana atau defisit. Dalam menjalankan usahanya sebagai lembaga keuangan yang menjual kepercayaan dan jasa, setiap bank berusaha sebanyak mungkin menarik nasabah baru, memperbesar danadananya dan juga memperbesar pemberian kredit dan jasa-jasanya (Simorangkir, 2004). Menurut Undang-Undang Perbankan No. 10 Tahun 1998, jenis perbankan terdiri dari Bank Umum dan Bank Perkreditan Rakyat (BPR). Sedangkan pada perbankan syariah BPR yang dimaksud yaitu Bank Pembiayaan Rakyat Syariah (BPRS).

Sebagian besar bank yang ada di Indonesia masih mengandalkan kredit sebagai pemasukan utama dalam membiayai operasionalnya. Menurut Siamat (2005) salah satu alasan terkonsentrasinya usaha bank dalam penyaluran kredit adalah sifat usaha bank sebagai lembaga intermediasi antara unit surplus dengan unit defisit, dan sumber utama dana bank berasal dari masyarakat sehingga secara moral mereka harus menyalurkan kembali kepada masyarakat dalam bentuk kredit. Sebagaimana umumnya negara berkembang, sumber pembiayaan dunia usaha di Indonesia masih didominasi oleh penyaluran kredit perbankan yang diharapkan dapat mendorong pertumbuhan ekonomi. Pemberian kredit merupakan aktivitas bank yang paling utama dalam menghasilkan keuntungan, tetapi risiko yang terbesar dalam bank juga bersumber dari pemberian kredit. Oleh karena itu pemberian kredit harus dikawal dengan manajemen risiko yang ketat (InfoBankNews.com, 2007 dalam Pratama, 2010).

Pada perbankan yang menjalankan prinsip syariah termasuk Bank Pembiayaan Rakyat Syariah (BPRS), istilah kredit tidak digunakan tapi diganti dengan istilah pembiayaan karena mempunyai prinsip yang berbeda. Tidak seperti kredit, pembiayaan lebih mengutamakan unsur kesepakatan dan transparansi sehingga nilai-nilai Islam tetap terjaga. Pada kenyataannya dari jumlah pembiayaan yang disalurkan kepada masyarakat tersebut tidak semua pembiayaan berkategori sehat tetapi diantaranya merupakan pembiayaan yang mempunyai kualitas buruk atau bermasalah. Pembiayaan bermasalah ini dalam dunia perbankan syariah disebut Non Performing Finance (NPF), ini merupakan fenomena yang sering terjadi dalam dunia perbankan syariah karena salah satu kegiatan utama perbankan syariah berasal dari penyaluran pembiayaan. Jika pembiayaan bermasalah melampaui batas, maka akan menjadi masalah serius yang akan mengganggu profitabilitas bank syariah yang berujung pada berhentinya operasional terutama pada bank syariah yang memiliki aset kecil seperti pada BPRS. Oleh karena itu perlu dicari faktor-faktor yang menyebabkan terjadinya pembiayaan bermasalah khususnya pada BPRS di Indonesia.

Beberapa hasil penelitian mengenai faktor-faktor yang berpengaruh terhadap terjadinya pembiayaan bermasalah baik faktor internal maupun eksternal telah dilakukan seperti pada beberapa penelitian berikut ini: 
Dari aspek internal, Adisaputra (2012) menemukan hasil bahwa BOPO berpengaruh positif terhadap NPL. Altunbas et al. (2000), Hughes and Mester (1993) dan Girardone et al. (2004) menemukan bahwa ada hubungan negatif antara bank yang tidak efisien (BOPO) dengan non performing loan. Begitupun Misra dan Dhal (2009) dalam Diyanti (2012) menemukan bahwa BOPO berpengaruh positif terhadap NPL. Faktor lainnya yaitu ukuran bank, pada penelitian Misra dan Dhal (2010) mengemukakan bahwa ukuran berpengaruh positif terhadap NPL. Sedangkan penelitian yang dilakukan oleh Ranjan dan Dhal (2003) dalam Kurnia (2013) menyatakan bahwa terdapat pengaruh negatif antara ukuran dengan NPL.

Adapun faktor penyebab pembiayaan bermasalah dari sisi eksternal yang direpresentasikan dengan Gross Domestic Product (GDP) dan inflasi. Salas dan Saurina (2002) menunjukkan adanya hubungan antara GDP dengan NPL. Hasil penelitian itu ditegaskan oleh Jimenez dan Saurina (2005) bahwa NPL dipengaruhi oleh GDP. Wu, et. al. (2003) dalam penelitian mereka menunjukkan bahwa GDP berpengaruh negatif signifikan terhadap kredit bermasalah. Sementara dalam penitian Rahmawulan (2008), Ahmed (2006) menunjukkan hal sebaliknya, GDP berpengaruh positif signifikan terhadap kredit bermasalah. Lain lagi penelitian Soebagia (2005), Nasution dan Williasih (2007), dalam penelitian mereka diketahui bahwa GDP tidak berpengaruh signifikan terhadap kredit bermasalah. Sedangkan penelitian seperti penelitian oleh Soebagio (2005), Rahmawulan (2008), dan Faiz (2010), diketahui bahwa inflasi berpengaruh positif signifikan terhadap kredit bermasalah. Sedangkan dalam penelitian Wu, et al. (2003) dan Ihsan (2011) dinyatakan tidak ada pengaruh signifikan antara inflasi terhadap kredit bermasalah.

Selain beberapa faktor di atas, kondisi likuiditas bank syariah juga dapat menentukan besarnya pembiayaan bermasalah. Karena jika kondisi bank syariah lebih likuid maka cenderung bank syariah lebih fleksibel dalam menyalurkan pembiayaan meskipun tingkat kemacetan sedang meningkat. Biasanya bank syariah lebih giat menangani pembiayaan bermasalah jika kondisi likuiditas sedang kurang baik. Dalam dunia perbankan syariah likuiditas diukur dengan Finance to Deposit Ratio sedangkan pada perbankan konvensional yaitu Loan to Deposit Ratio. Hasil penelitian Adisaputra (2012) menemukan hasil bahwa Loan to Deposit Ratio (LDR) berpengaruh positif terhadap NPL. Meskipun penelitian pada bank konvensional namun menunjukkan bahwa kredit macet berada pada saat likuiditas sedang baik. Meskipun demikian, ada pula hasil yang menunjukkan bahwa LDR berpengaruh negatif terhadap NPL (Faiz, 2010). Sehingga perlu dilakukan penelitian kembali untuk membuktikannya terutama pada BPRS di Indonesia.

Jika dilihat dari studi empiris, bahwa faktor internal (ukuran bank dan BOPO) serta faktor eksternal (Inflasi dan GDP) di atas ternyata berpengaruh pula terhadap likuiditas bank yang diukur dengan FDR/LDR. Hasil penelitian Ahmed et. al. (2011) dan Iqbal (2012) menunjukkan bahwa ukuran bank berhubungan positif terhadap likuiditas, Pramono (2006) menunjukkan BOPO berpengaruh negatif terhadap LDR, Nandadipa (2010) menunjukkan bahwa inflasi berpengaruh negatif terhadap LDR. Sedangkan GDP yang merupakan jumlah produk yang 
dihasilkan masyarakat akan berdampak pada jumlah saving yang disimpan di bank. Simpanan itulah yang akan meningkatkan DPK dan otomatis meningkatkan likuiditas bank. Sehingga diprediksi GDP berpengaruh positif terhadap likuiditas.

Oleh karena itu, likuiditas dalam hal ini FDR menjadi perantara hubungan antara ukuran bank, BOPO, inflasi dan GDP terhadap pembiayaan bermasalah. Akan tetapi hal ini perlu diuji kembali agar menemukan kepastian faktor yang berpengaruh terhadap pembiayaan bermasalah pada BPRS, apakah ukuran bank, BOPO, inflasi dan GDP mempengaruhi dulu likuiditas atau langsung berpengaruh terhadap pembiayaan bermasalah yang nantinya menjadi bahan pengambilan kebijakan pihak-pihak yang berkepentingan baik manajemen bank, masyarakat, maupun pemerintah.

Berdasarkan latar belakang hasil penelitian di atas baik penelitian dilakukan pada bank konvensional maupun bank syariah, baik yang dilakukan di dalam negeri maupun di luar negeri mengenai faktor-faktor yang berpengaruh terhadap pembiayaan bermasalah, masih perlu diuji kembali terutama dilakukan pada BPRS di Indonesia. Selain itu variabel likuiditas dijadikan sebagai variabel perantara (intervening/mediasi) untuk membuktikan kondisi likuiditas sebagai perantara faktor-faktor yang mempengaruhi pembiayaan bermasalah pada BPRS di Indonesia.

Alasan penelitian dilakukan pada BPRS karena BPRS adalah bank syariah yang paling mengena/lebih dekat pada masyarakat menengah ke bawah seperti untuk kebutuhan Usaha Mikro Kecil Menengah (UMKM) dan Usaha Kecil Menengah (UKM). Sedangkan UMKM/UKM adalah aktivitas perekonomian masyarakat mayoritas dilakukan di Indonesia yang tentunya sangat membutuhkan support dari lembaga keuangan terutama dalam hal pendanaan, sehingga diharapkan keberadaan BPRS mampu meningkatkan perekonomian Indonesia. Oleh karena itu penting dilakukan penelitian yang berkaitan dengan faktor yang berpengaruh terhadap pembiayaan bermasalah pada BPRS di Indonesia.

Bagian kedua dari paper ini akan mengulas teori dan studi literatur terkait, bagian ketiga menyajikan metodologi dan bagian keempat menguraikan hasil dan análisis. Kesimpulan akan diberikan pada bagian kelima dan menjadi penutup dari paper ini.

\section{TEORI}

Tingkat kelangsungan usaha bank berkaitan erat dengan aktiva produktif yang dimilikinya, oleh karena itu manajemen bank dituntut untuk senantiasa dapat memantau dan menganalisis kualitas aktiva produktif yang dimiliki. Kualitas aktiva produktif menunjukkan kualitas aset sehubungan dengan risiko kredit yang dihadapi oleh bank akibat pemberian kredit dan investasi dana bank. Aktiva produktif yang dinilai kualitasnya meliputi penanaman dana baik dalam rupiah maupun valuta asing, dalam bentuk kredit dan surat berharga (Siamat, 2005).

Risiko kredit yang diterima bank merupakan salah satu risiko usaha bank, yang diakibatkan dari tidak dilunasinya kembali kredit yang diberikan oleh pihak bank kepada debitur. Oleh 
karena itu kemampuan pengelolaan kredit sangat diperlukan oleh bank yang bersangkutan (Sinungan, 2000). Dalam penelitian ini karena penelitian digunakan pada BPRS, maka digunakan rasio NPF dalam menunjukkan kemampuan manajemen BPRS dalam mengelola pembiayaan bermasalah.

Non Performing Finance (NPF) merupakan rasio pembiayaan yang bermasalah di suatu bank. Apabila pembiayaan bermasalah meningkat maka resiko terjadinya penurunan profitabilitas semakin besar. Apabila profitabilitas menurun, maka kemampuan bank dalam melakukan ekspansi pembiayaan berkurang dan laju pembiayaan menjadi turun. Resiko pembiayaan yang diterima bank merupakan salah satu risiko usaha bank, yang diakibatkan dari tidak dilunasinya kembali pinjaman yang diberikan atau investasi yang sedang dilakukan oleh pihak bank (Muhammad, 2005 : 359).

NPF sangat berpengaruh terhadap pengendalian biaya dan sekaligus juga berpengaruh terhadap kebijakan pembiayaan yang akan dilakukan bank itu sendiri. Non Performing Finance (NPF) dapat mendatangkan dampak yang tidak menguntungkan terlebih lagi kalau NPF dalam jumlah besar. Peningkatan jumlah NPF akan meningkatkan jumlah Penyisihan Penghapusan Aset Produktif (PPAP) yang perlu dibentuk oleh pihak bank. Jika hal itu berlangsung terus maka akan mengurangi modal bank. Oleh karena itu kemampuan pengelolaan pembiayaan sangat diperlukan oleh bank syariah khususnya BPRS.

Salah satu faktor yang diprediksi mempengaruhi pembiayaan bermasalah adalah ukuran bank. Pada perbankan ukuran lebih cenderung dilihat dari total asetnya mengingat produk utamanya adalah pembiayaan serta investasi. Bank dengan aset yang besar memliki kemungkinan untuk menghasilkan keuntungan yang lebih besar apabila diikuti dengan hasil dari aktivitasnya. Menurut Misra dan Dhal (2010) bank-bank besar lebih cenderung memiliki tingkat kredit macet lebih tinggi karena kendala neraca, bank-bank kecil bisa menunjukkan lebih manajerial efisiensi dari bank-bank besar dalam hal penyaringan pinjaman dan pemantauan pasca pinjaman, yang menyebabkan tingkat kegagalan lebih rendah. Pernyataan ini ditegaskan oleh penelitian yang dilakukan oleh Kurnia (2013) menemukan hasil bahwa ukuran berpengaruh positif terhadap NPL. Namun penelitian yang dilakukan oleh Ranjan dan Dhal (2003) dalam Kurnia (2013) menyatakan bahwa terdapat pengaruh negatif antara ukuran dengan NPL. Berdasarkan teori dan hasil penelitian yang merujuk pada pernyataan Misra dan Dhal (2010), maka hipotesis pertama yang akan diuji adalah bahwa ukuran bank berpengaruh positif terhadap pembiayaan bermasalah.

Salah satu ukuran efisiensi BPRS adalah rasio BOPO (Biaya Operasional Pendapatan Operasional), yaitu rasio biaya operasional yang dikeluarkan untuk menghasilkan pendapatan operasional. Rasio BOPO ini berkaitan erat dengan kegiatan operasional BPRS, yaitu penghimpunan dana dan penggunaan dana. Biaya operasional BPRS yang terlalu tinggi atau sama dengan pendapatan operasional tidak akan mendatangkan keuntungan bagi BPRS. Pendapatan BPRS yang tinggi dengan biaya operasional yang rendah dapat menekan rasio BOPO 
sehingga BPRS berada pada posisi sehat, yang artinya kencederungan untuk meminimalisir terjadinya kredit macet dapat diatasi.

Semakin kecil rasio ini berarti semakin efisien biaya operasional yang dikeluarkan bank yang bersangkutan. Menurut Dendawijaya (2009:98) rasio biaya operasional digunakan untuk mengukur tingkat efisiensi dan kemampuan bank dalam melakukan kegiatan operasinya. Menurut ketentuan Bank Indonesia efisiensi operasi diukur dengan BOPO dengan batas maksimum BOPO adalah 90\%.

Hasil penelitian Altunbas et. al. (2000) menemukan bahwa ada hubungan negatif antara bank yang tidak efisien dengan non performing loan. Hasil penelitian ini konsisten dengan Hughes dan Mester (1993), Girardone et al. (2004), serta beberapa penelitian di dalam negeri seperti hasil penelitian Adisaputra (2012) menunjukkan bahwa BOPO berpengaruh positif terhadap NPL; dan ini menjadi hipotesis kedua yang akan diuji.

Faktor lain yang diprediksi berpengaruh terhadap pembiayaan bermasalah yaitu GDP sebagai variabel makroekonomi. Menurut McEachern (2000) dalam Diyanti (2012), GDP artinya mengukur nilai pasar dari barang dan jasa akhir yang diproduksi oleh sumber daya yang berada dalam suatu negara selama jangka waktu tertentu, biasanya satu tahun. Menurut Sukirno (2004) pertumbuhan ekonomi merupakan pertumbuhan GDP yang dalam hal ini tingkat pertumbuhan GDP adalah pada tahun tertentu dibandingkan dengan tahun sebelumnya. Peningkatan konsumsi yang diiringi dengan menurunnya investasi dan tingkat GDP riil maka mengindikasikan penurunan dalam memproduksi barang dan jasa (Soebagio, 2005). Hal tersebut akan mempengaruhi tingkat hasil usaha yang diperoleh perusahaan yang merupakan sumber dana dalam pembayaran kredit dari lembaga perbankan. Oleh karena itu hipotesis ketiga yang dibangun adalah GDP berpengaruh negatif terhadap kredit bermasalah.

Variabel makroekonomi lainnya yaitu Inflasi. Menurut Kamus Bank Indonesia, inflasi adalah keadaan perekonomian yang ditandai oleh kenaikan harga secara cepat sehingga berdampak pada menurunnya daya beli, sering pula diikuti menurunnya tingkat tabungan dan atau investasi karena meningkatnya konsumsi masyarakat dan hanya sedikit untuk tabungan jangka panjang.

Menurut Martono dan Harjito (2008) dalam Diyanti (2012), inflasi akan mempengaruhi kegiatan ekonomi baik secara makro maupun mikro termasuk kegiatan investasi. Inflasi juga menyebabkan penurunan daya beli masyarakat yang berakibat pada penurunan penjualan. Penurunan penjualan yang terjadi dapat menurunkan return perusahaan. Penurunan return yang terjadi akan mempengaruhi kemampuan perusahaan dalam membayar angsuran kredit. Pembayaran angsuran yang semakin tidak tepat menimbulkan kualitas kredit semakin buruk bahkan terjadi kredit macet (Taswan, 2006) sehingga akan meningkatkan nilai Non Performing Finance. 
Seperti hasil penelitian Soebagio (2005) dan Greenidge \& Grosvenor (2010) yang menyimpulkan bahwa semakin tinggi tingkat inflasi maka akan semakin tinggi pula tingkat NPL; dan ini merupakan hipotesis keempat yang diuji dalam paper ini.

Selain keempat faktor di atas, kondisi likuiditas BPRS tentunya membuat BPRS merasa lebih fleksibel dalam menyikapi pembiayaan bermasalah. Likuiditas yang diukur dengan FDR atau Finance to Deposit Ratio digunakan untuk mengukur jumlah dana pihak ketiga yang disalurkan dalam bentuk pembiayaan. Rasio FDR yang tinggi menunjukkan bahwa BPRS meminjamkan seluruh dananya (loan-up) atau relatif tidak likuid (illiquid). Artinya, semakin banyak dana yang dikeluarkan dalam pembiayaan, maka semakin tinggi FDR, dan kemungkinan terjadi resiko pembiayaan bermasalah/macet semakin tinggi pula.

Hasil penelitian Misra dan Dhal (2009) dalam Diyanti (2012) yang didukung oleh Adisaputra (2012) menunjukkan bahwa LDR berpengaruh positif terhadap NPL. Namun bertentangan dengan penelitian Faiz (2010) dan Soebagio (2005) menunjukkan LDR berpengaruh negatif terhadap NPL. Mengacu pada teori dan hasil penelitian di atas, hipotesis kelima yang dibangun adalah bahwa likuiditas berpengaruh positif terhadap pembiayaan bermasalah.

Studi empiris mengenai likuiditas bank baik konvensional maupun syariah yang diukur dengan LDR/FDR membuktikan bahwa keempat variabel di atas yaitu variabel-variabel yang diprediksi mempengaruhi pembiayaan bermasalah juga diprediksi mempengaruhi likuiditas. Berikut dijelaskan masing-masing hubungan variabel tersebut:

Ukuran bank diukur dengan total aset. Semakin besar aset yang dimiliki maka diharapkan akan semakin besar hasil operasional perusahaan (Syafitri, 2011). Penelitian yang pernah dilakukan Akhtar et al. (2011) tentang manajemen risiko likuiditas antara bank syariah dan bank konvensional di Pakistan menghasilkan temuan bahwa Size of the firm memiliki hubungan positif tetapi tidak signifikan terhadap variabel likuiditas pada bank konvensional maupun bank syariah. Sedangkan penelitian Ahmed et. al. (2011) dan Iqbal (2012) memperoleh hasil bahwa ukuran bank berhubungan positif dan signifikan terhadap likuiditas. Pada hipotesis kelima di atas, menyebutkan bahwa likuiditas berpengaruh positif terhadap pembiayaan bermasalah. Sedangkan hipotesis pertama menyebutkan ukuran bank berpengaruh positif terhadap pembiayaan bermasalah. Oleh karena itu diduga bahwa likuiditas menjadi perantara hubungan antara ukuran bank dengan pembiayaan bermasalah pada BPRS (hipotesis keenam).

BOPO atau Operating Expense to Operating Income dihitung dengan menggunakan perbandingan antara Beban Operasi dengan Pendapatan Operasi atau yang biasa disingkat dengan BOPO di Indonesia (Siamat, 2003). BOPO menunjukkan tingkat efisiensi suatu bank, sehingga semakin kecil rasio ini maka semakin efisiensi. Dengan efisiensi maka bank dapat memaksimalkan laba yang tentunya akan berdampak pada likuiditas bank. Telah dibuktikan sebelumnya oleh Pramono (2006) bahwa BOPO berpengaruh negatif terhadap LDR. Artinya semakin kecil BOPO makin semakin besar likuiditas bank. Sedangkan pada hipotesis kelima bahwa likuiditas diprediksi berpengaruh terhadap pembiayaan bermasalah dan hipotesis kedua 
menyebutkan BOPO berpengaruh positif terhadap pembiayaan bermasalah. Oleh karena itu diduga likuiditas menjadi perantara hubungan antara BOPO dengan pembiayaan bermasalah pada BPRS (hipotesis ketujuh).

Gross Domestic Bruto (GDP) merupakan nilai barang atau jasa dalam suatu negara yang diproduksi oleh faktor-faktor produksi milik warga negara negara tersebut dan negara asing. GDP merefleksikan kegiatan penduduk di suatu negara dalam memproduksi suatu barang dalam kurun waktu tertentu (Sukirno, 1998). Oleh karena itu peningkatan GDP menunjukkan kondisi baik pada suatu negara hal ini terkait pula dengan pendapatan masyarakat yang akan disimpan di bank syariah termasuk BPRS menjadi sumber dana pihak ketiga. Jika dana pihak ketiga pada BPRS meningkat maka menunjukkan likuiditas BPRS dalam keadaan baik. Hal inilah yang memprediksi bahwa GDP berpengaruh positif terhadap likuiditas. Namun hipotesis kelima menyebutkan bahwa likuiditas berpengaruh positif terhadap pembiayaan bermasalah dan hipotesis ketiga menyebutkan GDP berpengaruh negatif terhadap pembiayaan bermasalah. Sehingga diduga likuiditas menjadi perantara pengaruh GDP terhadap pembiayaan bermasalah pada BPRS (hipotesis kedelapan).

Inflasi yang dapat diartikan sebagai kenaikan harga barang secara terus-menerus sehingga mengakibatkan menurunnya daya beli masyarakat. Dengan demikian masyarakat tidak mampu untuk melakukan saving di bank. Hal inilah yang mengakibatkan menurunnya simpanan dana pihak ketiga (DPK) pada bank syariah. Dengan menurunnya unsur DPK maka likuiditas bank syariah khususnya BPRS menjadi menurun pula. Hasil penelitian Nandadipa (2010) membuktikan bahwa inflasi berpengaruh negatif terhadap likuiditas bank. Sedangkan pada hipotesis kelima bahwa likuiditas diprediksi berpengaruh positif terhadap pembiayaan bermasalah dan hipotesis keempat menyebutkan inflasi berpengaruh positif terhadap pembiayaan bermasalah. Oleh karena itu diduga likuiditas menjadi perantara hubungan antara inflasi dengan pembiayaan bermasalah pada BPRS (hipotesis kesembilan).

\section{METODOLOGI}

Populasi yang digunakan dalam penelitian ini adalah seluruh BPRS yang ada di Indonesia pada tahun 2010 sampai dengan tahun 2012 dengan data yang diambil dari statistik perbankan syariah. Sehingga data yang diperoleh adalah data rata-rata dari seluruh BPRS yang ada di Indonesia. Periode data yang diambil yaitu data bulanan sehingga dari 3 tahun periode pengamatan maka diperoleh 36 observasi. Sedangkan untuk variabel makroekonomi yaitu GDP dan inflasi diambil dari badan pusat statistik (BPS).

Teknik analisis yang digunakan adalah dua macam. Pertama analisis regresi berganda dengan persamaan kuadrat terkecil (ordinary least square/OLS) untuk menjawab hipotesis 1 , 2, 3, 4 dan 5 dengan model dasar sebagai berikut: 


$$
N P F_{t}=\alpha_{0}+\alpha_{1} U B_{t}+\alpha_{2} B O P O_{t}-\alpha_{3} G D P_{t}+\alpha_{4} I N F_{t}+\alpha_{5} F D R_{t}+\varepsilon
$$

Sedangkan analisis kedua menggunakan sobel test dan bootstraping atau analisis jalur yang dikembangkan oleh Ghazali (2013) dengan persamaan sebagai berikut:

$$
\begin{array}{l|c}
F D R_{t}=\alpha_{0}+\alpha_{1} U B_{t}+\varepsilon & N P F=\alpha_{0}+\alpha_{1} U B_{t}+\alpha_{5} F D R_{t}+v_{T} \\
F D R_{t}=\alpha_{0}+\alpha_{1} B O P O_{t}+\varepsilon & N P F_{t}=\alpha_{0}+\alpha_{2} B O P O_{t}+\alpha_{5} F D R_{t}+v_{T} \\
F D R_{t}=\alpha_{0}+\alpha_{1} G D P_{t}+\varepsilon & N P F_{t}=\alpha_{0}+\alpha_{3} G D P_{t}+\alpha_{5} F D R_{t}+v_{T} \\
F D R_{t}=\alpha_{0}+\alpha_{1} I N F_{t}+\varepsilon & N
\end{array}
$$

Dimana NPF $=$ Non Performing Finance, UB = Ukuran Bank, BOPO = Biaya Operasional terhadap Pendapatan Operasional, GDP = Gross Domestic Product, INF = Inflasi, FDR = Finance to Deposit Ratio dan e = error

Variabel dependen dalam penelitian ini adalah pembiayaan bermasalah yang dihitung dari semua pembiayaan yang macet (dalam logaritma natural). Variabel bebas meliputi (i) ukuran bank yang diukur dari total aset BPRS; dalam logaritma natural; (ii) BOPO (Biaya Operasional terhadap Pendapatan Operasional), yakni rasio yang mengukur tingkat efisiensi bank dalam mengelola biaya operasional untuk menghasilkan pendapatan operasional; (iii) GDP (Gross Domestic Product), dan (iv) Inflasi.

Variable mediasi yang merupakan variabel perantara (intervening), meliputi likuiditas; diukur dengan finance to deposit ratio (FDR). Rumus yang digunakan untuk menghitung FDR adalah sebagai berikut:

$$
\text { FDR } \frac{\text { Jumlah Pembiayaan yang disalurkan }}{\text { Total Deposit }} \times 100 \%
$$

Hipotesis dalam penelitian ini dipengaruhi oleh nilai signifikansi koefisien variabel yang bersangkutan setelah dilakukan pengujian. Kesimpulan hipotesis 1 sampai 5 dilakukan berdasarkan t-test (uji t) untuk menguji signifikansi variabel-variabel independen terhadap variabel dependen sedangkan F-test digunakan untuk menguji ketepatan model persamaan OLS. Sedangkan kesimpulan hipotesis 6 sampai 9 didasarkan pada nilai signifikansi pada indirect effect output sobel test. Pengujian hipotesis tersebut dilakukan jika telah memenuhi pengujian 
kualitas data melalui uji asumsi klasik yang terdiri dari uji normalitas, uji heteroskedastisitas, uji autokorelasi dan uji multikolinieritas.

\section{HASIL DAN ANALISIS}

Sebelum menganalisis hipotesis, terlebih dahulu dilakukan uji kualitas data untuk memastikan data layak dilakukan pengujian hipotesis. Pengujian dilakukan dengan uji asumsi klasik yang terdiri dari uji normalitas, uji autokorelasi, uji heteroskedastisitas dan uji multikolinieritas. Hasil pengolahan kualitas data disajikan pada Tabel 1.

\begin{tabular}{|c|c|c|c|c|c|}
\hline \multicolumn{6}{|c|}{$\begin{array}{c}\text { Tabel } 1 \\
\text { Uji Asumsi Klasik }\end{array}$} \\
\hline \multicolumn{6}{|c|}{ Pengujian Asumsi Klasik } \\
\hline Durbin Watson & & & & 1.45 & \\
\hline Glejser Test & Sig. & $\begin{array}{l}\text { UB } \\
\text { FDR } \\
\text { BOPO } \\
\text { GDP } \\
\text { INFLASI }\end{array}$ & & $\begin{array}{l}0,86 \\
0,31 \\
0,88 \\
0,63 \\
0,17\end{array}$ & \\
\hline Collinearity Statistics & VIF. & $\begin{array}{l}\text { UB } \\
\text { FDR } \\
\text { BOPO } \\
\text { GDP } \\
\text { INFLASI }\end{array}$ & $\begin{array}{l}7.224 \\
2.262 \\
4.306 \\
2.903 \\
1.251\end{array}$ & $\begin{array}{l}\text { TOL. UB } \\
\text { FDR } \\
\text { BOPO } \\
\text { GDP } \\
\text { INFLASI }\end{array}$ & $\begin{array}{l}0,138 \\
0,442 \\
0,232 \\
0,345 \\
0,800\end{array}$ \\
\hline
\end{tabular}

Pengujian kualitas data yang pertama yaitu uji normalitas data. Model regresi yang baik adalah yang memiliki distribusi normal atau mendekati normal, yang digunakan untuk menguji apakah variabel independen (terikat) dan variabel dependen (bebas) dalam model regresi mempunyai distribusi normal atau tidak. Pengujian distribusi normal dilakukan dengan uji Kolmogorov-Smirnov. Jika nilai Asymp. Sig (2-tailed) lebih besar dari 0,05, maka data dinyatakan berdistribusi normal. Hasil uji normalitas (Kolmogorov Smirnov) dapat dilihat pada tabel 1 bahwa nilai Asymp. Sig (2-tailed) yaitu 0,910. Nilai ini lebih besar dari 0,05 atau 5\%. Sehingga dapat disimpulkan bahwa data dinyatakan berdistribusi normal.

Uji autokorelasi bertujuan untuk menguji apakah model regresi linear ada korelasi antara kesalahan pengganggu pada periode t dengan kesalahan periode t-1 (sebelumnya). Jika terjadi korelasi, maka dinamakan ada problem autokorelasi. Autokorelasi muncul karena observasi yang berurutan sepanjang waktu berkaitan satu sama lainnya. Model regresi yang baik adalah yang bebas dari autokorelasi (Ghozali, 2006). Berdasarkan hasil analisis regresi uji autokorelasi pada tabel 1, nilai Durbin Watson (DW) sebesar 1,456. Sedangkan berdasarkan tabel Durbin 
Watson (DW) dengan $\mathrm{k}=5$ dan $\mathrm{n}=36$ maka nilai $\mathrm{dL}=1,176$ dan $\mathrm{dU}=1,799$, maka 4- $\mathrm{dU}=2,201$ dan 4-dL=2,824. Oleh karena itu nilai DW berada di antara dL dan dU, daerah ini merupakan daerah tanpa kesimpulan dan bukan bukan pada daerah yang terjadi outokorelasi.

Uji selanjutnya yaitu heteroskedastisitas. Uji ini digunakan untuk mengetahui ada atau tidaknya ketidaksamaan varian dari residual pada model regresi (Priyatno, 2008). Prasyarat yang harus terpenuhi dalam uji ini adalah tidak adanya masalah heteroskedastisitas. Untuk mendeteksi ada tidaknya heteroskedastisitas maka digunakan Uji Glejser. Dari tabel 1 dapat diketahui bahwa nilai sig. semua variabel independen lebih dari besar dari 0,05. Hal ini berarti tidak terjadi gejala heteroskedastisitas pada model regresi.

Pengujian kualitas data selanjutnya adalah uji multikoliniearitas. Uji multikoliniearitas data dapat dilakukan dengan matriks korelasi dengan melihat besarnya nilai VIF (variance inflation factor) dan tolerance. Suatu model regresi yang bebas dari multikolinearitas memiliki angka VIF di sekitar kurang dari angka 10 dan angka tolerance lebih besar dari 0,1. Pada tabel 1 menunjukkan bahwa nilai VIF dari masing-masing variabel independen kurang dari angka 10 dan nilai tolerance (TOL) yang diperoleh menunjukkan lebih dari angka 0,1. Dari hasil tersebut dapat diketahui bahwa dalam model regresi terbebas dari multikolonieiritas antar variabel independen. Dengan demikian semua hasil uji kualitas data (asumsi klasik) telah lolos dan data layak untuk digunakan.

Setelah pengujian asumsi klasik selesai dan dinyatakan bahwa kualitas data adalah baik, maka selanjutnya dilakukan pengujian hipotesis 1 sampai 5, dengan terlebih dahulu menguji ketepatan model (uji F).

\begin{tabular}{|c|c|c|c|}
\hline \multicolumn{4}{|c|}{$\begin{array}{c}\text { Tabel } 2 \\
\text { Hasil Perhitungan Uji F dan Uji t }\end{array}$} \\
\hline \multirow{2}{*}{\multicolumn{2}{|c|}{ Uji F }} & $\mathbf{F}$ & Sig. \\
\hline & & 12.019 & $.000^{\mathrm{a}}$ \\
\hline Uji t & \begin{tabular}{|l} 
UB \\
BOPO \\
GDP \\
Inflasi \\
FDR
\end{tabular} & $\begin{array}{r}-1.110 \\
-.060 \\
-2.231 \\
-2.462 \\
3.308\end{array}$ & $\begin{array}{l}.276 \\
.952 \\
.033 \\
.020 \\
.002\end{array}$ \\
\hline
\end{tabular}

Berdasarkan tabel 2 diperoleh hasil bahwa nilai signifkansi sebesar 0,000 atau lebih kecil dari batas nilai signifkansi $(\alpha=0,05)$. Sehingga model dikatakan baik dan variabel independen dapat digunakan secara bersama-sama untuk menjelaskan variabel dependen.

Hasil estimasi analisis diperoleh nilai signifikansi variabel ukuran bank yaitu sebesar 0,276 dengan koefisien negatif, dapat disimpulkan bahwa ukuran bank tidak berpengaruh terhadap 
NPF. Dengan demikian hipotesis pertama ditolak. Ukuran bank tidak berpengaruh terhadap NPF yang artinya besar kecilnya total aset pada BPRS tidak mempunyai dampak terhadap besarnya pembiayaan bermasalah. Artinya faktor pembiayaan bermasalah lebih ditentukan kepada bagaimana pengelolaan operasi bank dalam mengelola dan menganalisis pembiayaannya bukan ditentukan pada besarnya aset yang dimiliki. Ini terbukti terjadi pada BPRS bukan pada bank umum syariah ataupun unit usaha syariah.

Variabel kedua yaitu BOPO dengan nilai signifikansi yaitu sebesar 0,952 dan nilai koefisien negatif, maka disimpulkan BOPO tidak berpengaruh terhadap NPF. Dengan demikian hipotesis kedua ditolak. BOPO yang merupakan indikator efisiensi bank tidak lantas dapat mengurangi rasio pembiayaan macet, hal ini dikarenakan pembiayaan macet adalah urusan eksternal BPRS yang berhubungan langsung dengan masyarakat dalam membayar kewajibannya bukan tergantung pada efisiensi operasional BPRS. Sehingga efisiensi BPRS bukanlah menjadi patokan manajemen dalam mengambil kebijakan mengenai pengelolaan pembiayaan bermasalah.

Variabel ketiga yaitu GDP dengan nilai signifikansi yaitu 0,033 dan koefisien negatif maka disimpulkan GDP berpengaruh negatif terhadap pembiayaan bermasalah. Dengan demikian hipotesis ketiga diterima. GDP yang menunjukkan indikator majunya perekonomian masyarakat menunjukkan kemampuan dalam membayar kewajibannya terhadap BPRS. Oleh karena itu dengan meningkatnya GDP maka semakin mampu masyarakat dalam melunasi kewajibannya, begitu pun sebaliknya semakin menurunnya GDP maka semakin meningkat kemacetan dalam pembayaran kewajibannya. Secara statistik tinggi rendahnya GDP yang merupakan indikator makroekonomi akan berdampak pada tinggi rendahnya pembiayaan bermasalah pada BPRS yang secara tidak langsung akan berpengaruh pula pada perolehan laba.

Variabel keempat yaitu inflasi dengan nilai signifikansi sebesar 0,020 dan koefisien negatif, maka dapat disimpulkan bahwa inflasi berpengaruh negatif terhadap pembiayaan bermasalah. Dengan demikian hipotesis keempat ditolak. Penolakan hipotesis ini tentunya mempunyai alasan. Inflasi yang merupakan indikator makroekonomi tidak lantas membuat BPRS menjadi kuatir, karena secara statistik terbukti bahwa disaat masyarakat menurun daya belinya ternyata masyarakat tidak mengurangi kewajibannya dalam melunasi hutang pembiayaannya. Hal ini merupakan penemuan hal baru dalam dunia perbankan karena secara teori jika kekuatan perekonomian masyarakat melemah maka masyarakat makin tidak mampu dalam membayar kewajibannya. Akan tetapi fenomena ini membuktikan bahwa inflasi tidak akan merusak kualitas pembiayaan sehingga jelas terbukti bahwa BPRS dapat membantu masyarakat di saat masyarakat membutuhkan permodalan untuk usahanya.

Variabel kelima yaitu likuiditas yang diukur dengan FDR mempunyai nilai signifikansi sebesar 0,002 dengan koefisien positif, maka FDR berpengaruh positif terhadap pembiayaan bermasalah. Dengan demikian hipotesis kelima diterima. Hal ini berarti semakin likuid keuangan BPRS maka semakin luwes menyalurkan pembiayaan dan BPRS akan semakin gencar dalam menyalurkan pembiayaan. Dampak yang dirasakan adalah semakin tinggi pula pembiayaan 
macet. Artinya pembiayaan yang disalurkan oleh BPRS mempunyai resiko yang tinggi terhadap kemacetan berbanding dengan banyaknya penyaluran dana. Ini yang akan menjadi perhatian khusus bagi BPRS dalam menganalisis penyaluran pembiayaan dari sudut pandang likuidasi.

Langkah selanjutnya yaitu pengujian hipotesis 6 sampai 9 dalam rangka menguji likuiditas sebagai variabel mediasi antara variabel independen terhadap variabel dependen, maka dilakukan dengan menggunakan sobel test dan bootstraping. Berdasarkan hasil pengujian dengan menggunakan IBM SPSS ver. 21 diperoleh output yang disajikan pada tabel 3:

\begin{tabular}{|c|c|c|}
\hline \multicolumn{3}{|c|}{$\begin{array}{c}\text { Tabel } 3 \\
\text { Hasil Perhitungan Sobel Test }\end{array}$} \\
\hline Variables In Simple Mediation Model & $\mathbf{Z}$ & Sig (two) \\
\hline $\begin{array}{c}Y(N P F) \\
X(\text { UB) } \\
M(\text { FDR })\end{array}$ & $-1,4413$ & 1495 \\
\hline $\begin{array}{c}\text { Y (NPF) } \\
\text { X (BOPO) } \\
\text { M (FDR) }\end{array}$ & $-1,5300$ &, 1260 \\
\hline $\begin{array}{l}Y(N P F) \\
X(G D P) \\
M(\text { FDR) }\end{array}$ & 1,2631 & ,2065 \\
\hline $\begin{array}{l}\text { Y (NPF) } \\
X(\text { INF) } \\
M(\text { FDR) }\end{array}$ & 1,4543 & , 1459 \\
\hline
\end{tabular}

Tabel 3 merupakan ringkasan hasil olahan output sobel test dan bootstraping data penelitian mengenai pengujian variabel mediasi sehingga dapat dilihat nilai signifikansinya untuk menjawab hipotesis yang telah diajukan sebelumnya. Nilai signifikansi diambil dari output "Indirect Effect And Significance Using Normal Distribution". Jika nilai signifikansi kurang dari 0,05 maka variabel likuiditas merupakan variabel mediasi dan sebaliknya.

Pengujian pertama yaitu dalam hubungan antara ukuran bank dan NPF, nilai signifikansi variabel mediasi (FDR) sebesar 0,1495 dengan koefisien negatif. Nilai ini lebih besar dari 0,05 yang artinya likuiditas tidak memediasi hubungan antara ukuran bank dengan pembiayaan bermasalah. Hal ini memberikan bukti statistik bahwa besar kecilnya ukuran bank pada BPRS tidak berpengaruh terhadap baik buruknya kualitas pembiayaan baik secara langsung maupun tidak langsung melalui likuiditas. Oleh karena itu, manajemen BPRS dalam mengambil kebijakan mengenai pengelolaan pembiayaan bermasalah tidak dilihat dari sudut besar kecilnya kepemilikan aset karena tidak mampu menjadi variabel yang dapat memprediksi kemacetan pembiayaan yang disalurkan kepada masyarakat.

Pengujian kedua yaitu dalam hubungan antara BOPO dengan NPF, nilai signifikansi variabel mediasi (FDR) sebesar 0,1260 dengan koefisien negatif. Karena nilai ini lebih besar dari 
0,05 maka likuiditas tidak memediasi hubungan antara BOPO dengan pembiayaan bermasalah. Kaitan dengan hasil pengujian sebelumnya yang menghasilkan BOPO tidak berpengaruh terhadap pembiayaan bermasalah, maka pengujian mediasi ini membuktikan bahwa baik secara langsung maupun tidak langsung melalui likuiditas bahwa efisiensi (BOPO) tidak mempengaruhi pembiayaan bermasalah. Artinya efisiensi yang dihasilkan oleh BPRS dalam menjalankan operasionalnya tidak mampu memberikan dampak terhadap pembiayaan bermasalah karena pembiayaan bermasalah terkait dengan pihak luar yaitu nasabah bukan pada efisiensi di internal BPRS. Oleh karena itu variabel BOPO juga bukan menjadi sudut pandang manajemen BPRS dalam menganalisis pembiayaan bermasalah.

Pengujian ketiga yaitu dalam hubungan antara GDP dengan NPF, nilai signifikansi variabel mediasi (FDR) sebesar 0, 2065 dengan koefisien positif. Karena nilai signifikansi lebih besar dari 0,05 maka dapat disimpulkan likuiditas tidak memediasi hubungan antara GDP dengan pembiayaan bermasalah. Berkaitan dengan pengujian hipotesis ketiga bahwa hasilnya menunjukkan GDP berpengaruh negatif terhadap pembiayaan bermasalah, pengujian mediasi ini memperkuat hipotesis tersebut bahwa GDP secara langsung mempengaruhi pembiayaan bermasalah tanpa melalui likuiditas dulu. Artinya saat GDP dalam keadaan naik makan akan berdampak langsung pada menurunnya kualitas pembiayaan sehingga kenaikan GDP adalah sinyal positif bahwa masyarakat akan mampu melunasi kewajibannya kepada BPRS.

Pengujian variabel mediasi keempat yaitu hubungan antara inflasi terhadap NPF, hasil analisis menunjukkan bahwa nilai signifikansi FDR yaitu sebesar 0,1459 dengan koefisien positif. Karena nilai ini lebih besar dari 0,05 maka likuiditas tidak memediasi hubungan antara inflasi dengan pembiayaan bermasalah. Kaitan dengan hipotesis keempat yang menghasilkan bahwa inflasi berpengaruh positif terhadap pembiayaan bermasalah, maka pengujian ini memperkuat bahwa inflasi secara langsung mempengaruhi pembiayaan bermasalah tanpa harus melalui likuiditas dulu. Sebagai indikator makroekonomi tentunya inflasi terkait dengan kemampuan masyarakat dalam membayar kewajiban melunasi utang pembiayaannya yang akan berdampak pada besar kecilnya pembiayaan bermasalah tanpa harus mempengaruhi dulu kondisi likuiditas BPRS. Jika inflasi dalam keadaan naik maka akan berdampak pada naiknya pembiayaan bermasalah, sehingga manajemen BPRS harus mewaspadai keadaan inflasi dalam mengambil kebijakan mengenai pembiayaan bermasalah agar pembiayaan bermasalah dapat diminimalisir.

\section{KESIMPULAN}

Paper ini menganalisis pembiayaan bermasalah pada Bank Pembiayaan Rakyat Syariah (BPRS) di Indonesia. Hasil estimasi dan analisis memberikan beberapa temuan empiris; pertama, GDP berpengaruh negatif terhadap pembiayaan bermasalah. Artinya jika perekonomian sedang naik maka pembiayaan bermasalah pada BPRS akan berkurang sehingga GDP menjadi sinyal positif bagi BPRS. Kedua, inflasi berpengaruh negatif terhadap pembiayaan bermasalah. Artinya 
inflasi yang merupakan indikator lemahnya ekonomi/daya beli masyarakat tidak lantas membuat BPRS menjadi panik karena masyarakat terbukti akan mengutamakan kepentingan kewajibannya dalam membayar/melunasi hutang pembiayaannya. Ketiga, likuiditas berpengaruh positif terhadap pembiayaan bermasalah. Artinya likuiditas yang merupakan indikator mikroekonomi/ internal pengelolaan keuangan BPRS berdampak pada tingginya pembiayaan bermasalah. Semakin likuid maka semakin luwes dalam menyalurkan pembiayaan tetapi mempunyai resiko yang tinggi pula sehingga harus ada perhatian khusus dari manajemen.

Paper ini juga menemukan bahwa ukuran bank dan rasio biaya operasional terhadap pendapatan operasional (BOPO) tidak berpengaruh terhadap pembiayaan bermasalah pada BPRS. Hal ini memberikan bukti statistik bahwa besar kecilnya total aset serta efisiensi BPRS tidak berpengaruh terhadap non-performing loan mereka.

Selain itu, berdasarkan hasil analisis sobel test dengan bootstraping data membuktikan bahwa likuiditas BPRS yang diukur dengan Finance to Deposit Ratio (FDR), tidak memediasi pengaruh ukuran bank, BOPO, GDP dan inflasi terhadap pembiayaan bermasalah.

Berdasarkan penelitian ini, penulis memberikan saran yang hendak disampaikan diantaranya: 1) Penelitian ini hanya menggunakan 4 (empat) variabel independen dan satu variabel mediasi sehingga dibutuhkan variabel lain agar dapat diketahui penyebab lain terjadinya pembiayaan bermasalah pada BPRS di Indonesia, 2) Variabel yang diprediksi menjadi perantara variabel independen terhadap variabel dependen dapat diganti dengan variabel lain agar diketahui apakah ada variabel yang menjadi perantara (mediasi) hubungan keduanya, 3) Periode penelitian hanya 3 tahun sehingga untuk menambah keyakinan hasil penelitian maka periode penelitian dapat diperpanjang. 


\section{DAFTAR PUSTAKA}

Adisaputra, Iksan. (2012). Analisis Faktor-Faktor Yang Mempengaruhi Non-Performing Loan pada PT. Bank Mandiri (PERSERO)". Skripsi UNHAS Makasar, tidak dipublikasikan.

Ahmed, Neveed., et al. (2011). Risk Management Practices and Islamic Banks: An Empirical Investigation from Pakistan. Interdisciplinary Journal of Research in Business, Vol. 1, No. 6, pp. 50-57.

Ahmed, Syeda Zabeen. (2006). An Investigation of The Relationship between Non-Performing Loans, Macroeconomic Factors, and Financial factors in Context of Private Commercial Bank in Bangladesh. Bangladesh: Independent University.

Akhtar, et al. (2011). Liquidity Risk Management: A Comparative Study Between Conventional and Islamic Bank of Pakistan. Interdisciplinary Journal of Research in Business, Vol. 1, No. 1, pp. 35-44

Altunbas, Y., Liu, M. H., Molyneux, P., Seth, R. (2000). Efficiency and Risk in Japanese Banking. Journal of Banking and Finance, Vol. 24, pp.1605-1628.

Bank Indonesia. (2012). Statistik Perbankan Syariah.

. (2011). Statistik Perbankan Syariah. (2010). Statistik Perbankan Syariah.

Dendawijaya, Lukman. (2009). Kredit Bank. Jakarta: PT. Mutiara Sumber Widya.

Diyanti, Anin. (2012). Analisis Pengaruh Faktor Internal Dan Eksternal Terhadap Terjadinya Non-Performing Loan. Skripsi UNDIP.

Faiz, Ihda A. (2010). Ketahanan Kredit Perbankan Syariah Terhadap Krisis Keuangan Global. Jurnal ekonomi Islam La Riba. Vol 4, No. 2.

Ghozali, Imam. (2006). Aplikasi Analisis Multivariate Dengan Program SPSS. Semarang: Badan Penerbit Universitas Diponegoro.

(2013). Aplikasi Multivariate Dengan Program IBM SPSS. Semarang: Badan Peneribit Undip.

Girardone, C., Molyneux, P., dan Gardener, E. P. (2004). Analysing the Determinants of Bank Efficiency: The Case of Italian Banks. Applied Economics, 36, pp. 215-227.

Greenidge, Kevin dan Tiffany Grosvenor. (2010). Forecasting Non-Performing Loans in Barbados. Barbados: Research Department, Central Bank of Barbados, Tom Adams Financial Centre, Bridgetown. 
Hughes, J. P., dan Mester, L. J. (1993). A Quality and Risk-adjusted Cost Function for Banks: Evidence on the 'Too-Big-to-Fail' Doctrine. Journal of Productivity Analysis, 4, pp. 293315.

Ihsan, Muntoha. (2011). Pengaruh Gross Domestic Product Inflasi, dan Kebijakan Jenis Pembiayaan terhadap Rasio Non-Performing Financing Bank umum Syariah di Indonesia periode 2005 Sampai 2010. Skripsi UNDIP.

InfoBankNews.com. (2007). Bank Asing Bakal Smackdown Bank BUMN pada 2007?. Retrieved: 21 Maret 2007.

Iqbal, Anjum. (2012). Liquidity Risk Management: A Comparative Study Between Conventional and Islamic Bank of Pakistan. Global Journal of Management and Business Research, Vol. 12 , No. 5, 54-64.

Jimenez, Gabriel dan Jesus Saurina. (2005). Credit cycles, credit risk, and prudential regulation. Banco de Espana, January.

Kurnia, Dwi Jayanti. (2013). Analisis Faktor-Faktor Yang Mempengaruhi Non-Performing Loan (Studi Pada Bank Umum Konvensional yang Go Public di Indonesia Periode 2008-2012). Skripsi UNDIP.

Martono dan Agus Harjito. (2008). Manajemen Keuangan. Yogyakarta : EKONISIA

McEachern, William. (2000). Ekonomi Makro - Pendekatan Kontemporer. Terj. Sigit Triandaru. Jakarta: Salemba Empat.

Misra, B.M. dan Sarat Dhal. (2010). Pro-Cyclical Management of Non-Performing Loans by The Indian Public Sector Banks. BIS Asian Research Papers, Juni.

Muhammad. (2005). Manajemen Bank Syariah. Yogyakarta: UPPAMP YKPN.

Nasution E, Mustafa dan Wiliasih. (2007). Profit Sharing dan Moral Hazard Dalam Penyaluran Dana Pihak Ketiga Bank Umum Syariah di Indonesia. Jurnal Ekonomi dan Pembangunan Indonesia, Vol. 8I, No. 02, pp. 105-129.

Pramono, Widi. (2006). Analisis Pengaruh Likuiditas, Modal, dan Efisiensi Bank Terhadap Pemberian Kredit (Studi Kasus Pada PT. Bank Rakyat Indnesia, Tbk.). Skripsi UNDIP Semarang, tidak dipublikasikan.

Pratama, Billy Arma. (2010). Analisis Faktor - Faktor Yang Mempengaruhi Kebijakan Penyaluran Kredit Perbankan. Tesis UNDIP Semarang, tidak dipublikasikan.

Rahmawulan, Yunis. (2008). Perbandingan Faktor Penyebab Timbulnya NPL dan NPF Pada Perbankan Konvensional dan Syariah di Indonesia. Tesis Universitas Indonesia, tidak dipublikasikan. 
Salas, Vincente dan Jesus Saurina. (2002). Credit Risk in Two Institutional Regimes: Spanish Commercial and Savings Banks. Journal of Financial Services Research, 22:3, pp. 203224.

Siamat, Dahlan. (2003). Manajemen Bank Umum. Jakarta: Balai Pustaka.

(2005). Manajemen Lembaga Keuangan : Kebijakan Moneter dan Perbankan. Jakarta : FE UI.

Simorangkir O.P. (2004). Seluk beluk Bank Komersial, cetakan kelima, Jakarta : Persada Indonesia.

Sinungan, Muchdarsyah. (2000). Manajemen Dana Bank. Edisi Kedua. Jakarta : PT. Bumi Aksara.

Soebagio, Hermawan. (2005). Analisis Faktor-Faktor yang Mempengaruhi terjadinya Non Performing Loan (NPL) pada Bank Umum Komersil. Tesis UNDIP Semarang, tidak dipublikasikan.

Sukirno, Sadono. (1998). Teori Pertumbuhan Ekonomi : Pengantar Ekonomi Makro. Jakarta : Rajawali Pers.

. (2004). Makro Ekonomi Teori Pengantar. Edisi-3. Jakarta: PT. Raja Grafindo Persada.

Syafitri, Erlina Dwi. (2011). Pengaruh CAR, NPL, LDR, NIM, dan Size terhadap Risiko Bisnis Bank. Skripsi Universitas Diponegoro. http://eprints.undip.ac.id/. Diakses tanggal 15 Juli 2012.

Undang-Undang Perbankan No. 10 Tahun 1998.

UU Perbankan No. 7 tahun 1992.

Wu, Chang dan Selvili. (2003). Banking System, Real Estate Markets and Non Performing Loans. International Real Estate. Review. Vol. 6 No. 1, pp. 43-62. 